\title{
STATUS OF DRAUGHT ANIMAL POWER (DAP) AND DAP BASED TECHNOLOGY OF CHANDRAPUR, NASHIK, SATARA AND SOLAPUR DISTRICTS OF MAHARSHTRA
}

\author{
A. B. Ghule ${ }^{1}$, B. S. Gholap ${ }^{2}$, A. Waghmode ${ }^{3}$, R. Gavhane ${ }^{4}$, S. H. Bhutada ${ }^{5}$ \\ ${ }^{1,3,4,5}$ Department of Farm Machinery and Power Engineering, Marathwada Agriculture University, Parbhani- \\ (Maharashtra) 431401 \\ ${ }^{2}$ AICRP on FIM, ICAR - Central Institute of Agricultural Engineering, Nabibagh, Bhopal \\ (Madhya Pradesh)- 462038
}

\begin{abstract}
A techno-economic study was conducted to study the status of draft animal power (DAP) and DAP based technology in Chandrapur, Nashik, Satara and Solapaur districts of Maharashtra. The parameters of the study mainly consisted of availability of draught animal power, status of bullock operated farm implements and machinery and facility regarding animal shelter, urine and cow dung disposal. The study revealed that, draught animal power had been extensively used for crop production and transportation. The most common breads are Khilari, Dangi, Deoni and Deshi. Bullocks over three years of age are the main sources of draught animals for field operations. Average observed DAP of Chandrapur, Nashik, Satara \& Solapur were 0.44, 0.27, $0.42 \& 0.35 \mathrm{kW/ha}$ respectively. It was concluded that, utilization of plough, harrow, seed-drill, cultivator and bullock cart were highest in Solapur 89.09 \%, Satara 32.72 \%, Nashik 32.30 \%, Solapur 56.36 \%, and Satara $56.36 \%$ respectively. The methods for collection of urine \& cow dung by hand were mostly used in Satara $70.90 \%$, by tool it was found highest in Nashik $56.15 \%$. Utilization of covered area of animal shelter was highest in Solapur $74.54 \%$ and uncovered area of animal shelter was highest in Nashik $35.38 \%$. The use of tractor, power tiller was highest in Satara $48.18 \%$, Nashik $6.15 \%$ respectively.
\end{abstract}

Keywords: Draught Animal Power(DAP), Breads, Animal Shelter, Animal Drawn Implements, Machinery.

\section{INTRODUCTION}

India posses the most famous draught breeds in the world (Phaniraja, 2009). These are Nagori, Khilari, Helikar, Dangi, Deoni, Amrit Mahal, Kangayam, Malvi, Hariana, Gir, Angol, Tharparkar and Gaulao. The average DAP availability was estimated as 3.68 ha per pair which is considered far below the normal command area of 1.5-2.5 ha per pair (Anonymous, 1990). In Maharashtra, the crossbred cattle have increased by $12.9 \%$ but indigenous cattle decreased by $13.4 \%$ during the period between 16 th and 17th census (Indian livestock census report, 2007). There is a decrease of $9.8 \%$ in total cattle population during inter seasonal period.

The state of Maharashtra has a geographic area of 3, 07,713 sq.km. This is $9.4 \%$ of the country's geographic area. The state has a forest cover of $47,482 \mathrm{sq} . \mathrm{km}$. As per the $17^{\text {th }}$ livestock census, the state of Maharashtra had $8.8 \%$ of Cattle, $6.28 \%$ of buffaloes, $5.03 \%$ of sheep, $8.59 \%$ of goats and $3.25 \%$ of pig population of the country. The state has the sixth highest buffaloes' population in the country.

In any agricultural crop production system human, draught animals and engines or motors provide the motive power in various proportions for crop production, harvesting, transport and processing (Rijk, 1989; FAO, 2003; Pearson, 2005). Draught animal is a reliable and popular farm power resource in most developing countries. With the modernization of agriculture, the use of mechanical power in agriculture has increased but DAP continues to be used on Indian farms due to small land holdings and hill agriculture. More than $55 \%$ of the total cultivated area is still being managed by using draught animals as against about $20 \%$ by tractors.

The traditional farm tools and implement mainly relied on use of animate power (Singh, G. 1989). Improved farm tools, implement and machinery are used by animal and mechanical power. The traditional animal operated country plough although having low output (30-40 h/ha) and requiring higher number of tillage operations are still being used by farmers on small farms and in regions where economic status of the farmers is not sound. This paper present the finding of this study covering the details of availability of draught animal power, status of bullock operated farm implements and machinery and facility regarding animal shelter, urine and cow dung disposal.

\section{MATERIALS AND METHODS}

\subsection{Study Area}

Out of nine agro climatic zone of Maharashtra Chandrapur, Nashik, Satara and Solapur districts from moderate rainfall zone, transition zone-1, transition zone- 2 and scarcity zone respectively were selected for study. A representative district having animal power close to animal power availability of agro climatic zone was selected; also origin of draft breeds of animal has given preference. 


\subsection{Selection of Sample}

From selected district one village was selected away from city and main source of family was based on draught animal power. Random samples of 450 farmers from all four districts of Maharshtra were selected for study. From each tehsil one village was selected, from each village ten farmers were selected from different socio-economic status of the farmers such as marginal, small, medium farmers and also cover general, SC/ST, OBC categories etc.

\subsection{The Design of Questionnaire}

After development of an outline of research work an interview questionnaire was prepared in Marathi language to the villagers. While preparing the questionnaire the objectives of the study were kept in view. It was designed in two parts i.e. Part-A and Part-B (Appendix-I and II)

Part-A : It was designed to obtain information from respondents regarding their personal, social and economical characteristics which includes items like land holding, living conditions, source and extent of income, farm power, social participation and source of irrigation.

Part-B: It was intended to collect information regarding estimated population of draught animal breed wise, animal power, annual use of animals, feed and fodder fed to animals during different periods of the year during work and rest, housing system, yoke and harness used.

\subsection{Pre-Testing of Questionnaire}

Before conducting the interviews the questionnaire was perfected in consultation and guidance of experts in the field in order to increase the reliability and validity of the questionnaire.

\subsection{Classification of Farmers}

The farmers of the village under the study were grouped into classes according to different socio-economic groups such as marginal, small, medium farmers and also cover general, $\mathrm{SC} / \mathrm{ST}$, OBC categories etc.

\subsection{Data Collection}

The data was collected through personal interview of farmers. For data collection one village was selected from each tehsil and ten farmers from each village.

\subsection{Analysis of Information}

The information collected through interviews was transferred from the questionnaire to proforma of farmer's survey (Srivastava N.S.L. and Ojha T.P. 1987).

DAP and $\%$ use of implement was calculated by:

a) DAP $(\mathrm{kW} / \mathrm{ha})=($ Total no. of Bullock $\times 0.5) \div($ Total Net Sown Area)

b) Use of Implement $(\%)=($ No. of farmer using implement $\times 100) \div$ Total No. of farmer.

\section{RESULTS AND DISCUSSION}

\subsection{Status of Chandrapur District}

The maximum net sown area was 1092.25 ha in Girgaon village of Sindevahi block and minimum about 605.50 ha in Bharanj village of Bhadravati block. The major crops grown were rice, soybean, tur and cotton. The total number of bullock maximum about 300 in Vishapur village of Ballarsha block and minimum about 40 in Bharanj village of Bhadravati block. The major implements were plough, harrow, puddler etc. The machinery like diesel engine and motor were also used. The detail is shown in table no. 1

Table.1 Information about the villages selected in Chandrapur district.

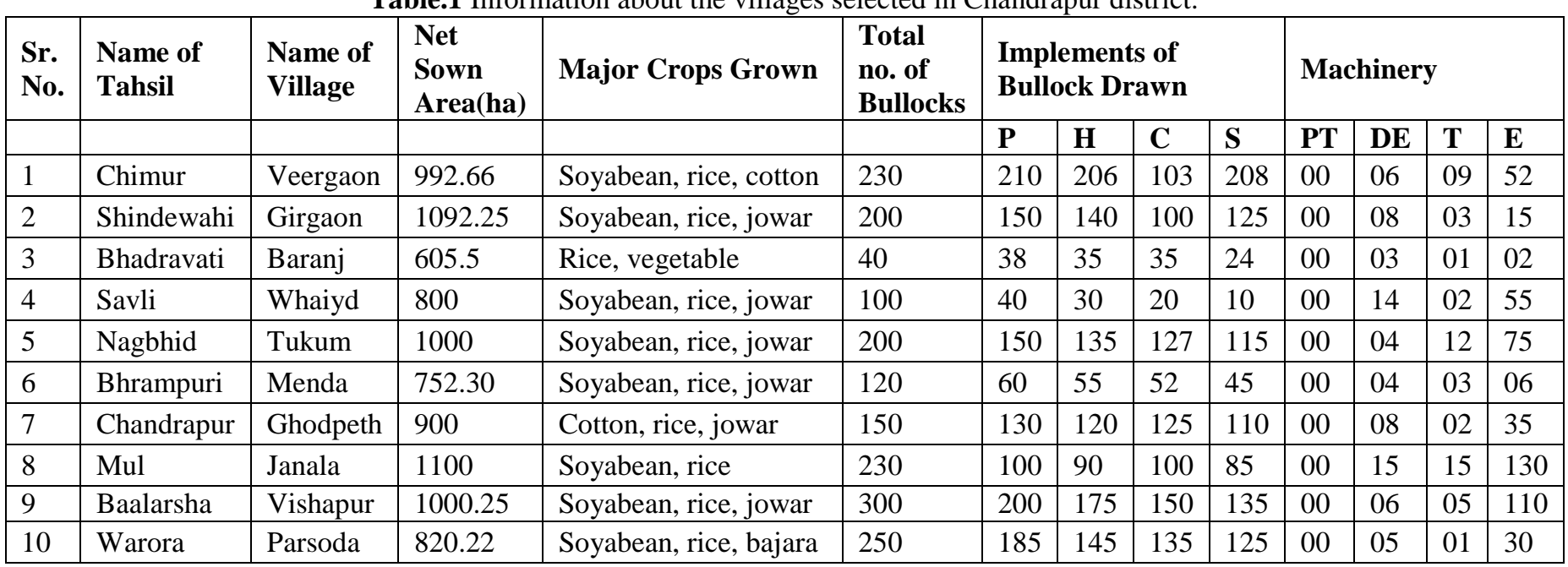

\subsection{Status of Nashik District}

The maximum net sown area was 8467.30 ha in Pimpalgaon village of Niphad block and minimum about 305.89 ha in Sogras village of Chandwad block. The major crops grown were pomegranate, onion, grape and maize. The total number of bullock maximum about 1300 in Nampur village of Satana block and minimum about 140 in Matane village of Devala block. The major implements were plough, harrow, seed-drill, cultivator etc. The machinery like diesel engine, motor and tractor were also used. The detail is shown in table no. 2 
Table 2 Information about the villages selected in Nashik district.

\begin{tabular}{|c|c|c|c|c|c|c|c|c|c|c|c|c|c|}
\hline \multirow[t]{2}{*}{$\begin{array}{l}\text { Sr. } \\
\text { No. }\end{array}$} & \multirow[t]{2}{*}{$\begin{array}{l}\text { Name of } \\
\text { Tahsil }\end{array}$} & \multirow[t]{2}{*}{$\begin{array}{l}\text { Name of } \\
\text { Village }\end{array}$} & \multirow[t]{2}{*}{$\begin{array}{l}\text { Net } \\
\text { Sown } \\
\text { Area(ha) }\end{array}$} & \multirow[t]{2}{*}{ Major Crops Grown } & \multirow[t]{2}{*}{$\begin{array}{l}\text { Total } \\
\text { no. of } \\
\text { Bullocks }\end{array}$} & \multicolumn{4}{|c|}{$\begin{array}{l}\text { Implements of } \\
\text { Bullock Drawn }\end{array}$} & \multicolumn{4}{|c|}{ Machinery } \\
\hline & & & & & & $\mathbf{P}$ & $\mathbf{H}$ & $\mathbf{C}$ & $\mathbf{S}$ & PT & DE & $\mathbf{T}$ & $\mathbf{E}$ \\
\hline 1 & Satana & Nampur & 7048.46 & Pomogranate,onion,jowar,wheat & 1300 & 800 & 809 & 600 & 900 & 01 & 15 & 16 & 880 \\
\hline 2 & Nashik & Mahirvani & 684.51 & Groundnut, makka,jowar,mug & 185 & 130 & 120 & 85 & 150 & 00 & 13 & 08 & 75 \\
\hline 3 & Trimbak & Anjneri & 1250.5 & Onion,groundnut, jowar, mug & 501 & 155 & 150 & 100 & 120 & 00 & 75 & 15 & 125 \\
\hline 4 & Dindori & Khedgaon & 3268 & Pomogranate, makka,jowar & 465 & 228 & 128 & 130 & 126 & 01 & 15 & 14 & 140 \\
\hline 5 & Nandgaon & Jalgaon & 696.31 & Grape, onion, wheat, mug,tur & 348 & 228 & 125 & 135 & 148 & 00 & 05 & 04 & 145 \\
\hline 6 & Kalwan & Manur & 782 & Onion,jowr, makka, wheat & 425 & 374 & 325 & 280 & 235 & 00 & 10 & 08 & 125 \\
\hline 7 & Igatpuri & Takhed & 4348 & Pomogranate,jowar, tur & 538 & 435 & 320 & 414 & 220 & 02 & 25 & 14 & 356 \\
\hline 8 & Yewla & Rajapur & 3176 & Pomogranate, grape, wheat & 887 & 515 & 320 & 230 & 110 & 00 & 12 & 12 & 320 \\
\hline 9 & Malegaon & Wadner & 2876.36 & Pomogranate, makka,tur & 386 & 385 & 370 & 320 & 312 & 00 & 19 & 12 & 150 \\
\hline 10 & Sinnar & Padoli & 315.46 & Grape,makka,jowar, tur & 248 & 230 & 220 & 118 & 160 & 00 & 12 & 05 & 148 \\
\hline 11 & Niphad & Pimplgaon & 8467.30 & Pomogranate, jowar, tur & 550 & 400 & 445 & 370 & 350 & 01 & 35 & 16 & 500 \\
\hline 12 & Devala & Matane & 325.65 & Pomogranate, makka,jowar, tur & 140 & 130 & 114 & 130 & 115 & 00 & 10 & 06 & 180 \\
\hline 13 & Chandwad & Sogras & 305.89 & Pomogranate, makka,jowar, tur & 150 & 135 & 112 & 118 & 125 & 00 & 12 & 05 & 120 \\
\hline
\end{tabular}

\subsection{Status of Satara District}

The maximum net sown area was 3215 ha in Mauli village of Satara block and minimum about 1200 ha in Sokasan village of Mann block. The major crops grown were onion, vegetable, jowar, bajra and maize. The total number of bullock maximum about 452 in Mauli village of Satara block and minimum about 110 in Jalgaon village of Koregaon block. The major implements were plough, harrow, seed-drill, cultivator etc. The machinery like diesel engine, motor and tractor were also used. The detail is shown in table no.3

Table. 3 Information about the villages selected in Satara district.

\begin{tabular}{|l|l|l|l|l|l|l|l|l|l|l|l|l|l|}
\hline $\begin{array}{l}\text { Sr. } \\
\text { No. }\end{array}$ & $\begin{array}{l}\text { Name of } \\
\text { Tahsil }\end{array}$ & $\begin{array}{l}\text { Name of } \\
\text { Village }\end{array}$ & $\begin{array}{l}\text { Net } \\
\text { Area(ha) }\end{array}$ & Major Crops Grown & \multicolumn{2}{|l|}{$\begin{array}{l}\text { Total } \\
\text { no. of } \\
\text { Bullocks }\end{array}$} & \multicolumn{2}{|l|}{$\begin{array}{l}\text { Implements of } \\
\text { Bullock Drawn }\end{array}$} & \multicolumn{3}{|l|}{ Machinery } \\
\hline & & & & & P & H & C & S & PT & DE & T & E \\
\hline 1 & Mahabaleshwar & Akade & 3211 & Maize, wheat,onion & 293 & 275 & 280 & 225 & 217 & 00 & 25 & 14 & 235 \\
\hline 2 & Wai & Bhuej & 2130 & Nachni, chavali, bajra, maize & 325 & 480 & 425 & 230 & 335 & 00 & 19 & 15 & 270 \\
\hline 3 & Maan & Sokasan & 1200 & Maize, onion, jowar & 150 & 85 & 31 & 42 & 70 & 00 & 08 & 06 & 95 \\
\hline 4 & Koregaon & Jalgaon & 1815 & Sugarcane, cotton, wheat & 110 & 100 & 80 & 65 & 75 & 01 & 12 & 15 & 150 \\
\hline 5 & Karad & Tambave & 1935 & Maize, tomato, mug, tur & 335 & 220 & 237 & 225 & 210 & 01 & 81 & 20 & 225 \\
\hline 6 & Jawali & Hateghar & 1360 & Ghewda, tur, sugarcane & 178 & 175 & 137 & 85 & 140 & 00 & 51 & 15 & 285 \\
\hline 7 & Waduj & Khatgun & 1040 & Ghewda, tur, maize & 163 & 137 & 120 & 110 & 125 & 01 & 17 & 11 & 265 \\
\hline 8 & Satara & Mauli & 3215 & Mirchi, vegetable, maize & 452 & 425 & 487 & 350 & 485 & 02 & 105 & 20 & 378 \\
\hline 9 & Khandala & Sukhed & 2305 & Jawari, mug, tur & 315 & 493 & 330 & 220 & 225 & 02 & 31 & 14 & 335 \\
\hline 10 & Patan & Umbraj & 1535 & Onion, maize, tur, wheat & 358 & 315 & 225 & 270 & 225 & 00 & 25 & 17 & 291 \\
\hline 11 & Phaltan & Barad & 1405 & Sugarcane, vegetable & 355 & 335 & 325 & 200 & 317 & 00 & 68 & 18 & 251 \\
\hline
\end{tabular}

\subsection{Status of Solapur District}

It is concluded that the maximum net sown area was 6300 ha in Kondi village of North Solapur block and minimum about 1779 ha in Sangavi village of Pandharpur block. The major crop grown was jowar, sugarcane, groundnut, bajra and tur. The total number of bullock maximum about 1300 in Phondshiras village of Malshiras block and minimum about 250 in Limbichincholi village of South Solapur. The major implements were plough, harrow, seed-drill, cultivator etc. The machinery like diesel engine, motor and tractor were used. The details shown in table no. 4 
Table.4 Information about the villages selected in Solapur district.

\begin{tabular}{|l|l|l|l|l|l|l|l|l|l|l|l|l|l|}
\hline $\begin{array}{l}\text { Sr. } \\
\text { No. }\end{array}$ & $\begin{array}{l}\text { Name of } \\
\text { Tahsil }\end{array}$ & $\begin{array}{l}\text { Name of } \\
\text { Village }\end{array}$ & $\begin{array}{l}\text { Net } \\
\text { Sown } \\
\text { Area } \\
\text { (ha) }\end{array}$ & Major Crops Grown & \multicolumn{2}{l|}{$\begin{array}{l}\text { Total } \\
\text { no. of } \\
\text { Bullocks }\end{array}$} & \multicolumn{2}{l|}{$\begin{array}{l}\text { Implements of } \\
\text { Bullock Drawn }\end{array}$} & \multicolumn{2}{l|}{ Machinery } \\
\hline & & & & & P & H & C & S & PT & DE & T & E \\
\hline 1 & Pandharpur & Sangavi & 1779 & Jawari, sugarcane, wheat & 305 & 275 & 250 & 225 & 204 & 02 & 65 & 06 & 315 \\
\hline 2 & Malshiras & Phondsiras & 4551 & Sugarcane, wheat, onion & 1300 & 805 & 430 & 305 & 515 & 01 & 32 & 13 & 900 \\
\hline 3 & Barshi & Pangaon & 3900 & Bajri, maize, jawar, tur & 800 & 650 & 350 & 275 & 350 & 00 & 25 & 15 & 950 \\
\hline 4 & Mangalwedha & Gunjegaon & 5200 & Karadi, onion, sugarcane & 795 & 495 & 270 & 320 & 225 & 01 & 15 & 18 & 775 \\
\hline 5 & South solapur & Limbichincholi & 2290 & Jowar, sugarcane, maize & 250 & 175 & 235 & 186 & 250 & 00 & 30 & 14 & 650 \\
\hline 6 & Akkalkoat & Karajl & 2060 & Maize, groundnut, jawar & 300 & 200 & 200 & 175 & 215 & 00 & 15 & 10 & 950 \\
\hline 7 & Mohol & Lamboti & 4900 & Sugarcane, jawar, onion & 610 & 351 & 315 & 228 & 340 & 00 & 20 & 15 & 650 \\
\hline 8 & Madha & Anjgaon & 4500 & Pomogranate, ber, wheat & 600 & 425 & 350 & 217 & 300 & 01 & 15 & 16 & 950 \\
\hline 9 & North solapur & Kondi & 6300 & Kardi, ber, groundnut & 630 & 460 & 310 & 380 & 315 & 00 & 15 & 14 & 490 \\
\hline 10 & Sangola & Mahot & 2900 & Wheat, sugarcane, maize & 325 & 215 & 185 & 190 & 305 & 00 & 15 & 13 & 305 \\
\hline 11 & Karmala & Kandar & 2155 & Jawari, wheat, cotton & 360 & 340 & 325 & 195 & 220 & 00 & 30 & 16 & 155 \\
\hline
\end{tabular}

Notations- $\quad$ P-plough, H-harrow, C-cultivator, S-seed drill, PT-power tiller, DE-diesel engine, T-tractor, E-electric motor

\subsection{Survey Result of the Selected Villages of}

\section{Chandrapur, Nashik, Satara and Solapur}

The maximum net sown area found in Nashik district as 361.6 ha and minimum in Chandrapur district as 206.6 ha. The maximum total number of bullocks were found in Solapur district as 223 and minimum in Chandrapur district as 183. The maximum number of plough and harrow were found in Solapur district as 98 and 35 respectively. The maximum number of seed-drill and cultivator were found in Nashik district as 42 and 66 respectively. The maximum tractors were found in Satara district as 53, the maximum power tillers and electric motors were found as 8 and 130 respectively in Nashik district as shown in table.5

Table.5 Survey result of the selected villages of Chandrapur, Nashik, Satara \& Solapur.

\begin{tabular}{|c|c|c|c|c|c|c|c|c|c|c|c|c|c|c|c|}
\hline \multirow[t]{2}{*}{$\begin{array}{l}\text { Sr. } \\
\text { No. }\end{array}$} & \multirow[t]{2}{*}{$\begin{array}{l}\text { Name of } \\
\text { District }\end{array}$} & \multirow[t]{2}{*}{$\begin{array}{l}\text { Total } \\
\text { net } \\
\text { Sown } \\
\text { Area(ha) }\end{array}$} & \multirow[t]{2}{*}{$\begin{array}{l}\text { Total } \\
\text { no. of } \\
\text { Bullock }\end{array}$} & \multicolumn{4}{|c|}{$\begin{array}{l}\text { Total no. of } \\
\text { Implement }\end{array}$} & \multirow[t]{2}{*}{$\begin{array}{l}\text { Total } \\
\text { no. } \\
\text { of } \\
\text { B.C. }\end{array}$} & \multicolumn{2}{|c|}{$\begin{array}{l}\text { Total no. of } \\
\text { Urine \& } \\
\text { C.D. } \\
\text { disposal }\end{array}$} & \multicolumn{2}{|c|}{$\begin{array}{l}\text { Animal } \\
\text { Shelter }\end{array}$} & \multicolumn{3}{|c|}{$\begin{array}{l}\text { Total no. of } \\
\text { O.P.S. }\end{array}$} \\
\hline & & & & $\mathbf{P}$ & $\mathbf{H}$ & $\mathbf{C}$ & $\mathbf{S}$ & & Hand & Tool & C/A & U/A & $\mathbf{T}$ & PT & $\mathbf{E}$ \\
\hline 1 & Chandrapur & 206.6 & 183 & 77 & 20 & 45 & 24 & 47 & 48 & 48 & 54 & 35 & 14 & 00 & 97 \\
\hline 2 & Nashik & 361.6 & 193 & 88 & 19 & 66 & 42 & 57 & 51 & 73 & 66 & 46 & 50 & 08 & 130 \\
\hline 3 & Satara & 226.4 & 193 & 93 & 36 & 46 & 16 & 62 & 78 & 39 & 81 & 22 & 53 & 04 & 110 \\
\hline 4 & Solapur & 316.2 & 223 & 98 & 35 & 62 & 32 & 58 & 60 & 61 & 82 & 26 & 40 & 03 & 110 \\
\hline
\end{tabular}

\subsection{Status of Utilization of Farm Implements,}

\section{Disposal of Urine, Cow Dung, Shelter and O.P.S.}

The utilization of plough, harrow, seed-drill, cultivator and bullock cart were highest in Solapur $89.09 \%$, Satara 32.72 $\%$, Nashik $32.30 \%$, Solapur $56.36 \%$, and Satara $56.36 \%$ respectively. The methods for collection of urine and cow dung by hand were mostly used in Satara $70.90 \%$, by tool it was found highest in Nashik $56.15 \%$. Utilization of covered area of animal shelter was highest in Solapur $74.54 \%$, and uncovered area of animal shelter was highest in Nashik $35.38 \%$. The use of tractor, power tiller was highest in Satara $48.18 \%$, Nashik $6.15 \%$ respectively. The details shown in table no.6

Table.6 Percent utilization of status of farm implements, disposal of urine \& cow dung, shelter \& O.P.S

\begin{tabular}{|l|l|l|l|l|l|l|l|l|l|l|l|l|l|}
\hline $\begin{array}{l}\text { Sr. } \\
\text { No. }\end{array}$ & Districts & $\begin{array}{l}\mathbf{P} \\
\mathbf{\%}\end{array}$ & $\begin{array}{l}\text { H } \\
\mathbf{\%}\end{array}$ & $\begin{array}{l}\text { S } \\
\mathbf{\%}\end{array}$ & $\begin{array}{l}\mathbf{C} \\
\mathbf{\%}\end{array}$ & $\begin{array}{l}\text { B.C. } \\
\mathbf{\%}\end{array}$ & \multicolumn{2}{l}{$\begin{array}{l}\text { Urine \& } \\
\text { C.D.\% }\end{array}$} & \multicolumn{2}{|l|}{$\begin{array}{l}\text { Animal } \\
\text { Shelter\% }\end{array}$} & $\begin{array}{l}\text { T } \\
\text { \% }\end{array}$ & $\begin{array}{l}\text { PT } \\
\text { \% }\end{array}$ & $\begin{array}{l}\text { E } \\
\text { \% }\end{array}$ \\
\hline & & & & & & & Hand & Tool & C/A & U/A & & & \\
\hline 1 & Chandrapur & 77 & 20 & 24 & 45 & 47 & 48 & 48 & 54 & 35 & 14 & 00 & 97 \\
\hline 2 & Nashik & 67.69 & 14.61 & $\mathbf{3 2 . 3 0}$ & 50.76 & 43.84 & 39.23 & $\mathbf{5 6 . 1 5}$ & 50.76 & $\mathbf{3 5 . 3 8}$ & 38.46 & $\mathbf{6 . 1 5}$ & $\mathbf{1 0 0}$ \\
\hline 3 & Satara & 84.54 & $\mathbf{3 2 . 7 2}$ & 14.52 & 41.81 & $\mathbf{5 6 . 3 6}$ & $\mathbf{7 0 . 9 0}$ & 35.45 & 73.63 & 20 & $\mathbf{4 8 . 1 8}$ & 3.63 & $\mathbf{1 0 0}$ \\
\hline 4 & Solapur & $\mathbf{8 9 . 0 9}$ & 31.81 & 29.09 & $\mathbf{5 6 . 3 6}$ & 52.72 & 54.54 & 55.45 & $\mathbf{7 4 . 5 4}$ & 23.63 & 36.36 & 2.72 & $\mathbf{1 0 0}$ \\
\hline
\end{tabular}

O.P.S. - other power sources 


\subsection{Draught Animal Power Availability per ha for}

\section{Chandrapur, Nashik, Satara and Solapur}

It is observed that draught animal power per ha is highest in Chandrapur district i.e. $0.44 \mathrm{~kW} / \mathrm{ha}$ followed by Nashik, Satara and Solapur, 0.27, 0.42 and $0.35 \mathrm{~kW} / \mathrm{ha}$ respectively, graphical representation shown in Fig.1

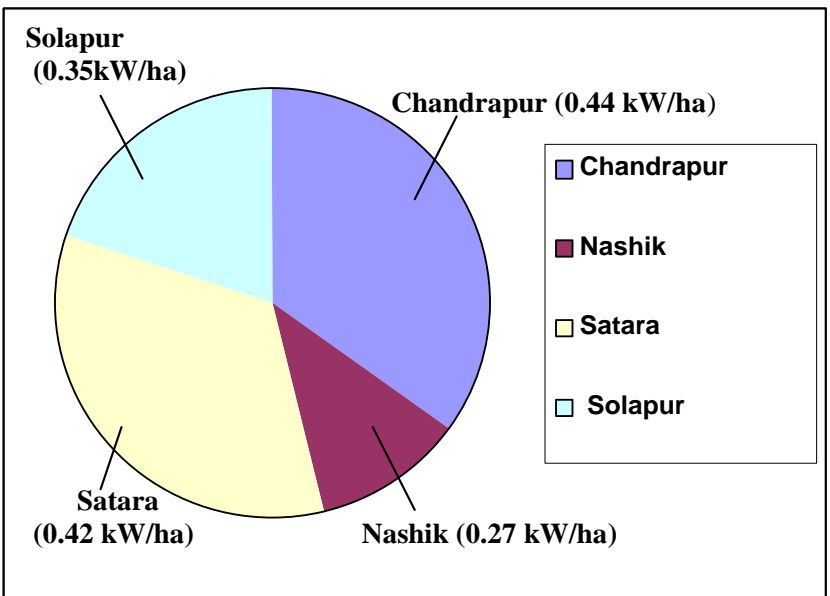

Fig. 1 Pie chart of draught animal power availability per ha for Chandrapur, Nashik, Satara \& Solapur district

\section{CONCLUSION}

From the results and discussion following conclusion could be drawn:

1) Average observed DAP of Chandrapur, Nashik, Satara and Solapur districts were $0.44,0.27,0.42$ and $0.35 \mathrm{~kW} / \mathrm{ha}$ respectively.

2) Utilization of tractor, bullock cart and harrow were highest in Satara district. Handling of cattle dung by traditional method (by hand) was highest in Satara district followed by Chandrapur, Nashik and Solapur districts.

3) During field operation the maximum use of seed drill and power tiller were found in Nashik district. Collection of cattle dung by tool was highest in Nashik district followed by Chandrapur, Satara and Solapur districts. Utilization of electric motor was highest in Nashik, Satara and Solapur districts .

4) During field operation use of seed drill, plough, cultivator and harrow were found maximum in Nashik district, ploughs and cultivators were found highest in Solapur district.

5) Covered area of animal shelter was highest in Solapur district while uncovered area was in Nashik district. Utilization of plough and cultivator were highest in Solapur district.

\section{REFERENCES}

[1] Anonymous, 1972, 1977, 19821987 and 2007. Indian Livestock Census reports. Directorate of Economics and Statistics, Department of Agriculture \&
Cooperation, Ministry of Agriculture, Government of India.

[2] Anonymous, 1990. Annual Reports of All India Coordinated Research Projects on Utilization of Animal Energy in Agriculture, Indian Council of Agricultural Research, New Delhi.

[3] Anonymous Rijk, 1989.

[4] Anonymous, FAO, 2003 report.

[5] Anonymous Pearson, 2005.

[6] Phaniraja, K.L. and Panchasara, H.H. 2009.Indian Draught Animals Power. Veterinary World, Vol.2(10):404-407.

[7] Singh, G. 1989. Energy Perspective-Norms and Scenario in Agriculture. Journal of Rural Energy 1(1): $1-10$.

[8] Srivastava N.S.L. and Ojha T.P. 1987. Utilization and Economics of Draught Animal Power. Technical Bulletin CIAE/ 87/51, Central Institute of Agricultural Engineering, Bhopal, India. 